\title{
Ascorbic acid toxicity is related to oxidative stress and enhanced by high light and knockdown of chloroplast ascorbate peroxidases in rice plants
}

\author{
Jamyla L. S. Castro • Yugo Lima-Melo • Fabricio E. L. Carvalho • \\ Antonio G. S. Feitosa - Milton C. Lima Neto - Andréia Caverzan • \\ Marcia Margis-Pinheiro • Joaquim A. G. Silveira $\mathbb{D}$
}

Received: 22 November 2017/ Accepted: 21 February 2018/Published online: 27 February 2018

(C) Brazilian Society of Plant Physiology 2018

\begin{abstract}
Toxicity caused by high concentrations of ascorbic acid (AA) has been widely reported in animal cells but is scarcely described in plants. In this study, rice plants deficient (knockdown) in two chloroplast ascorbate peroxidases (APX7/8) and non-transformed (NT) were exposed to wide exogenous AA concentrations in the presence of low light and high light (HL). Reduced (ASC) and oxidized (DHA) ascorbate reached much higher concentrations in symplast compared to the apoplastic space, and high redox states were found in both cellular compartments. Exogenous AA concentrations above $30 \mathrm{mM}$ caused strong cellular and oxidative damage indicated by decreased cell integrity and increased lipid peroxidation in leaves. These toxic effects were strongly enhanced by HL and, to a small extent, by deficiency
\end{abstract}

Electronic supplementary material The online version of this article (https://doi.org/10.1007/s40626-018-0100-y) contains supplementary material, which is available to authorized users.

J. L. S. Castro · Y. Lima-Melo - F. E. L. Carvalho ·

A. G. S. Feitosa · J. A. G. Silveira $(\square)$

Laboratório de Metabolismo de Plantas, Departamento de

Bioquímica e Biologia Molecular, Universidade Federal

do Ceará, Av. Humberto Monte 2825, Campus do Pici, B1

907., CP 6020, Fortaleza, CE CEP 60451-970, Brazil

e-mail: silveira@ufc.br

Y. Lima-Melo

Molecular Plant Biology, Department of Biochemistry,

University of Turku, Turku, Finland of both chloroplastic proteins APX7/8. The combination of HL and high AA concentration induced a strong increase in $\mathrm{H}_{2} \mathrm{O}_{2}$, associated with decrease in the content of chlorophylls and carotenoids. High AA concentrations strongly induced stomatal closure and impairment in $\mathrm{CO}_{2}$ assimilation, in combination with decreased quantum efficiency of photosystem II (PSII) and PSI. We postulate that oxidative stress caused by AA toxicity in the presence of HL was induced by overproduction of reactive oxygen species due to an imbalance between excess energy in the photosystems and low $\mathrm{CO}_{2}$ assimilation, which was related closely to strong decrease in stomatal conductance. In addition, high ASC levels might have acted as a pro-oxidant in the presence of high $\mathrm{H}_{2} \mathrm{O}_{2}$ concentrations, stimulating the Fenton reaction and contributing to the intensification of oxidative stress in rice leaves.

Keywords Ascorbic acid - Oryza sativa - Oxidative stress · Photo-oxidative stress · Photosynthesis ·

Reactive oxygen species

M. C. Lima Neto

State University of São Paulo, UNESP-CLP,

Experimental Campus of São Paulo Coast, São Vicente, SP, Brazil

A. Caverzan · M. Margis-Pinheiro

Department of Genetics, Federal University of Rio Grande do Sul, UFRGS, Porto Alegre, RS, Brazil 


$\begin{array}{ll}\text { Abbreviations } \\ \text { APX7/ } & \text { Knockdown plants in both chloroplast } \\ 8 & \text { ascorbate peroxidases APX7 and APX8 } \\ \text { NT } & \text { Non-transformed plants } \\ \text { HL } & \text { High light } \\ \text { LL } & \text { Low light } \\ \text { ASC } & \text { Reduced ascorbate } \\ \text { MDHA } & \text { Monodehydroascorbate } \\ \text { DHA } & \text { Dehydroascorbate } \\ \text { ROS } & \text { Reactive oxygen species } \\ \text { O }_{2}^{-} & \text {Superoxide } \\ \text { PPFD } & \text { Photosynthetic photons flux density } \\ \text { PSII } & \text { Photosystem II } \\ \text { PSI } & \text { Photosystem I } \\ \text { Fv/Fm } & \text { Indicator of maximum quantum yield of } \\ & \text { PSII } \\ \text { DPSII } & \text { Effective quantum yield of PSII } \\ \text { TBARS } & \text { Thiobarbituric acid-reactive substances } \\ \text { MD } & \text { Membrane damage } \\ \text { FW } & \text { Fresh weight } \\ \text { DTT } & \text { Dithiothreitol }\end{array}$

\section{Introduction}

Ascorbate (ASC) is a very important antioxidant involved in several physiological processes in higher plants, especially photosynthesis (Gest et al. 2013). The biosynthesis of ASC in plants occurs in a pathway derived from hexoses, with L-galactone (GL) as the precursor (Smirnoff 2000; Bulley and Laing 2016). The last steps of ASC synthesis occur in the mitochondrial inner membrane. Therefore, ASC molecules need to be exported from mitochondria to chloroplasts to play a role in photosynthesis (Foyer 2015). Plant cells can accumulate high ASC concentrations, which can vary from 2.5 to $25 \mathrm{mM}$ (Zechmann et al. 2011; Gest et al. 2013). In chloroplasts, ASC can reach elevated concentrations, as high as $30 \mathrm{mM}$ (Gest et al. 2013). Moreover, many reports have demonstrated that plants exposed to abiotic stress conditions, such as salinity and high light (HL), are able to strongly induce ASC biosynthesis (Bulley and Laing 2016).

Several studies have attempted to improve plant performance under abiotic stress by enhancing the ASC concentration through genetic manipulation of its synthesis or degradation processes (Ishikawa and Shigeoka 2008). In this context, genetic approaches have concentrated on inducing over-expression of the
L-galactose pathway and ascorbate regeneration-related genes (Hu et al. 2016). These approaches have allowed approximately 2-fold increases in the ASC content in different plant species (Eltayeb et al. 2007). In parallel to genetic methodologies, several efforts have utilized exogenous supplying of ASC or its precursor GL to successfully improve plant protection (Kostopoulou et al. 2015; Terzi et al. 2015). The exogenous GL and ASC concentrations utilized in such studies have varied widely, which could lead to prominent increases in the ASC content, up to 4-fold more than untreated plants (Pallanca and Smirnoff 1999).

In opposition to beneficial effects of ASC, several reports in the medical sciences have shown that high exogenous ascorbic acid (AA) concentrations can be toxic for animal cells, with the ability to kill cancerous cells and bacteria (Vilchèze et al. 2013). These authors proposed that the most important mechanism associated with AA toxicity would be related to its role as a powerful pro-oxidant agent. Indeed, ASC can reduce heavy metal ions such as $\mathrm{Fe}^{3+}$ to $\mathrm{Fe}^{2+}$, which can induce the accumulation of hydroxyl radicals through Fenton's reaction, subsequently causing oxidative stress (Carr and Frei 1999). Qian et al. (2014), working with Arabidopsis supplied with $8 \mathrm{mM}$ exogenous ASC, found evidence for toxicity by oxidative stress. Recently, Wu et al. (2017) demonstrated that $5 \mathrm{mM}$ ASC supplied to rice leaves in the presence of high $\mathrm{Fe}^{2+}$ induced oxidative stress. Although these authors did not describe the mechanisms of $\mathrm{ASC}+\mathrm{Fe}^{2+}$ toxicity, they attributed such effects to the enhancement of Fenton's reactions. Thus, high ASC concentrations, under certain physiological circumstances, especially high concentrations of metal ions, could be an important physiological problem (Tóth et al. 2017).

Changes in endogenous ascorbate concentrations due to genetic manipulation to induce changes in DHAR expression are associated with stomatal aperture regulation in wheat and tobacco plants (Zhang 2001; Chen and Gallie 2004). According to these authors, the induced alterations in ASC redox state are related to modulation of the $\mathrm{H}_{2} \mathrm{O}_{2}$ levels in guard cells. Because ASC can act as an electron donor for APX activity, reduced expression of DHAR could result in plants with low ASC content, which subsequently would lead to low APX activity and higher $\mathrm{H}_{2} \mathrm{O}_{2}$ levels in guard cells, which might promote stomatal 
closure (Zhang 2001; Chen and Gallie 2004). In contrast, plants over-expressing DHAR are more efficient at ASC recycling, which could contribute to increased APX activity, and therefore, they might display lower $\mathrm{H}_{2} \mathrm{O}_{2}$ accumulation. Under these conditions, reactive oxygen species (ROS) could trigger signaling mechanisms associated with stomata opening (Chen and Gallie 2004). However, the role played by high exogenous ASC concentrations on stomatal control has been poorly reported to date. Despite being widely described that chloroplastic APX activity is an important hub to regulate the $\mathrm{H}_{2} \mathrm{O}_{2}$ levels, which is involved with ASC-induced responses, its role in stomatal opening regulation has not been unequivocally demonstrated.

In this study, rice plants deficient (RNAi-knockdown) in both chloroplastic APX7 and APX8 were employed to study the possible oxidative stress induced by high AA concentrations since these plants present higher $\mathrm{H}_{2} \mathrm{O}_{2}$ concentrations (Caverzan et al. 2014). We hypothesized that these toxic effects are enhanced by both HL and deficiency in chloroplast APX7/8 due to $\mathrm{H}_{2} \mathrm{O}_{2}$ accumulation. Our results show that AA concentrations above $30 \mathrm{mM}$ cause toxicity by oxidative stress, being this effect strongly enhanced by HL, particularly in APX7/8-silenced plants. These constraints are related to stomatal closure, and this could be associated with ROS accumulation due to an imbalance between excess energy in the photosystems and low $\mathrm{CO}_{2}$ assimilation caused by a decrease in stomatal aperture. In parallel, high ASC levels could also have acted as a pro-oxidant in the presence of increased $\mathrm{H}_{2} \mathrm{O}_{2}$ concentrations, stimulating the Fenton reaction, and thereby contributing to the intensification of oxidative stress. The importance of these findings for plant biology is discussed.

\section{Materials and methods}

2.1 Construction of plant vectors, plant transformation and growth conditions

Double knockdown rice plants (Oryza sativa ssp. japonica cv. Nipponbare) for OsAPX7 and OsAPX8 (APX7/8) were obtained as previously described by Caverzan et al. (2014). A chimeric gene producing mRNA with a hairpin structure (hpRNA) was constructed based on the sequence of the OsAPX7
(LOC_Os04g35520) and OsAPX8 (LOC_Os02g34810) genes. The following primer pairs were used to amplify a 238-bp RNAi OsAPX7/8 sequence: 5'-CACCCTCTAAAGCTTGTCCAAC- $3^{\prime}$ and 5'-TCAAGACCCATCCTGTAA- $3^{\prime}$. The PCR products were cloned into the Gateway vector pANDA in which hpRNA transcription is driven by the maize ubiquitin promoter and an intron upstream of the inverted repeats (Upadhyaya et al. 2000; Miki and Shimamoto 2004). Rice seeds from the T2 generation of non-transformed (NT) and transgenic lines (APX7/8) in which the OsAPX7 and $O S A P X 8$ genes had been silenced were germinated on MS medium supplemented with hygromycin under controlled conditions $\left[150 \mu \mathrm{mol} \mathrm{m}{ }^{-2} \mathrm{~s}^{-1}\right.$ photosynthetic photon flux density (PPFD), $25{ }^{\circ} \mathrm{C}, 80 \%$ relative humidity and a 12-h photoperiod]. Previously, 10 APX8/7 lines were phenotyped and characterized by RT-qPCR, and the s-2 line was chosen to represent the silenced transgenic plants (Caverzan et al. 2014). Two weeks after sowing, rice seedlings (APX7/8-s2 and NT plants) were transferred to 2-L plastic pots that were filled with half-strength Hoagland-Arnon nutrient solution. The $\mathrm{pH}$ was adjusted to $6.0 \pm 0.5$ every 2 days, and the nutrient solution was changed weekly. The seedlings were kept for 45 days in a greenhouse under the following natural conditions: day/night mean temperature of $29 / 24{ }^{\circ} \mathrm{C}$ (day/night), mean relative humidity of $78 \%$ and a photoperiod of $12 / 12 \mathrm{~h}$ (light/dark). The PPFD in the greenhouse varied according to typical diurnal patterns in equatorial zones, reaching an average maximum PPFD of $870 \mu \mathrm{mol} \mathrm{m}^{-2} \mathrm{~s}^{-1}$ at noon, with sunrise at 6:00 a.m. and sunset at 6:00 p.m.

\subsection{Supplying of exogenous AA for leaf segments}

Forty-five-day-old APX7/8 and NT plants were grown as previously described. The plants were acclimated in a growth chamber at $27 \pm 2 / 24 \pm 2{ }^{\circ} \mathrm{C}$ (day/night) and $70 \pm 5 \%$ humidity with a PPFD of $500 \mu \mathrm{mol} \mathrm{m} \mathrm{m}^{-2} \mathrm{~s}^{-1}$ and a 12-h photoperiod for $48 \mathrm{~h}$. Leaf segments were collected from mature leaves (middle $4-6 \mathrm{~cm}$ ), washed with $1.5 \mathrm{mM} \mathrm{CaCl}_{2}$ for $1 \mathrm{~min}$ and immersed in solution $(10 \mathrm{mM}$ HEPES buffer, $\mathrm{pH} 6.5$, containing $1.5 \mathrm{mM} \mathrm{CaCl}_{2}$ and $0.01 \%$ Triton X-100) with AA (Sigma-Aldrich, USA). The Petri dishes (20 segments per plate) were kept under continuous $200 \mu \mathrm{mol} \mathrm{m} \mathrm{m}^{-2} \mathrm{~s}^{-1}$ (low light, LL) or $1000 \mu \mathrm{mol} \mathrm{m}^{-2} \mathrm{~s}^{-1}$ (HL) for $24 \mathrm{~h}$. All experiments 
were performed utilizing AA dissolved in the previously described buffered medium to avoid direct toxicity caused by its acidity. Leaf segments in the presence of the same buffer containing $1.5 \mathrm{mM} \mathrm{CaCl}_{2}$ and $0.01 \%$ Triton X-100 (v/v) but without AA were used as controls. After the treatments, the leaf segments were washed with $1.5 \mathrm{mM} \mathrm{CaCl}{ }_{2}$ solution for $1 \mathrm{~min}$ to eliminate superficial AA and then used for chlorophyll $a$ fluorescence measurements and electrolyte leakage evaluation. Samples were rapidly immersed in liquid $\mathrm{N}_{2}$ and immediately stored in a freezer at $-85{ }^{\circ} \mathrm{C}$ for further biochemical measurements.

\subsection{Measurements of ASC and DHA levels in apoplast and symplast}

Leaf segments ( $1 \mathrm{~g}$ per $50 \mathrm{~mL}$ of incubation medium) were initially immersed for $24 \mathrm{~h}$ in Petri plates in medium containing $50 \mathrm{mM}$ AA (Sigma-Aldrich, USA) in the presence of $10 \mathrm{mM}$ HEPES buffer, $6.5 \mathrm{pH}$, containing $1.5 \mathrm{mM} \mathrm{CaCl}_{2}$ and $0.01 \%$ Triton $\mathrm{X}-100(\mathrm{v} / \mathrm{v})$ in the dark. After this period, leaf segments were washed with $1.5 \mathrm{mM} \mathrm{CaCl}_{2}$ for $1 \mathrm{~min}$ to eliminate excess ASC/DHA. These compounds accumulated inside apoplast were released to an external solution containing $1.5 \mathrm{mM} \mathrm{CaCl}_{2}$ after a 30-min incubation at $2{ }^{\circ} \mathrm{C}$ (passive efflux). Total efflux of ASC and DHA was measured after release to external medium by a 60 -min incubation at $28{ }^{\circ} \mathrm{C}$. The symplast ASC/DHA content was determined by the difference between the total and apoplastic effluxes as previously described (Aragão et al. 2016). The times chosen for determination of both effluxes were based on previous efflux kinetic curves. The ASC and DHA concentrations in the symplast and apoplast were expressed as \% of total efflux.

\subsection{Supplying of exogenous AA to whole plants}

Forty-five-day-old APX7/8 and NT plants previously grown in a greenhouse were transferred to a growth chamber as previously described and acclimated for $48 \mathrm{~h}$. To test ascorbate toxicity on intact plants, $50 \mathrm{mM}$ AA (Sigma-Aldrich, USA) was dissolved in $10 \mathrm{mM}$ HEPES buffer, $6.5 \mathrm{pH}$, containing $1.5 \mathrm{mM}$ $\mathrm{CaCl}_{2}$ and $0.01 \%$ Triton $\mathrm{X}-100$. This solution was sprayed in excess on the shoots until complete wetting was achieved. The first application was performed at
6:00 p.m. under dark conditions, and the second application was performed $12 \mathrm{~h}$ later, at the onset of the photoperiod (6:00 a.m.). After supplying AA, plants were exposed to two light regimes, $500 \mu \mathrm{mol} \mathrm{m} \mathrm{m}^{-2} \mathrm{~s}^{-1}$ (moderate light, ML) and $1000 \mu \mathrm{mol} \mathrm{m}{ }^{-2} \mathrm{~s}^{-1}$ (HL) for $12 \mathrm{~h}$. Control plants were sprayed similarly with the same buffer solution without AA and exposed to $500 \mu \mathrm{mol} \mathrm{m} \mathrm{m}^{-2} \mathrm{~s}^{-1}$. After the in vivo photosynthesis measurements (gas exchange and photochemical activity), the leaves were washed with distilled water to eliminate surface AA, and samples were immediately harvested, immersed in liquid $\mathrm{N}_{2}$ and stored in a freezer at $-85^{\circ} \mathrm{C}$ for further biochemical measurements.

\subsection{Membrane damage and lipid peroxidation}

Membrane damage (MD) was measured by electrolyte leakage, as described by Blum and Ebercon (1981). Twenty leaf segments were placed in test tubes containing $20 \mathrm{~mL}$ of deionized water. The flasks were incubated in a shaking water bath $\left(25^{\circ} \mathrm{C}\right)$ for $12 \mathrm{~h}$, and the electrical conductivity in the medium was measured (L1). Leaf discs were then boiled $\left(95^{\circ} \mathrm{C}\right)$ for $60 \mathrm{~min}$ in closed tubes and cooled to $25^{\circ} \mathrm{C}$, and then the electrical conductivity was measured again (L2). The relative $\mathrm{MD}$ was estimated by $\mathrm{MD}=(\mathrm{L} 1 /$ L2) $\times 100$. Lipid peroxidation was measured based on the formation of thiobarbituric acid-reactive substances (TBARS; Cakmak and Horst 1991). The concentration of TBARS was calculated using its absorption coefficient $\left(155 \mathrm{mM}^{-1} \mathrm{~cm}^{-1}\right)$, and the results were expressed as $\eta$ mol of malondialdehydethiobarbituric acid per gram of fresh weight ( $\eta$ mol MDA-TBA g FW ${ }^{-1}$ ).

2.6 Gas exchange, chlorophyll $a$ fluorescence, P700 absorption and photosynthetic pigment measurements

The net $\mathrm{CO}_{2}$ assimilation rate $\left(\mathrm{P}_{\mathrm{N}}\right)$ and stomatal conductance $\left(\mathrm{g}_{\mathrm{s}}\right)$ were measured using a portable infrared gas analyzer (IRGA) system equipped with an LED source and leaf chamber (IRGA LI-6400XT, LiCor $^{\circledR}$, USA). The IRGA chamber had the following internal parameters: $1000 \mu \mathrm{mol} \mathrm{m} \mathrm{s}^{-2} \mathrm{~s}^{-1}$ PPFD, $1.0 \pm 0.2 \mathrm{kPa}$ VPD, $38 \mathrm{~Pa} \mathrm{CO}_{2}$ and $28{ }^{\circ} \mathrm{C}$. The amount of blue light was set to $10 \%$ of the PPFD to maximize the stomatal aperture (Flexas et al. 2008). 
A Dual-PAM-100 (Heinz Walz, Germany) was used for the simultaneous measurement of PSII and PSI photochemical parameters based on chlorophyll $a$ fluorescence and the P700 oxidation signal (Klughammer and Schreiber 1998).

Chlorophyll fluorescence was measured via the saturation pulse method (Schreiber et al. 1995) in illuminated leaves or segments followed by $30 \mathrm{~min}$ of dark adaption. For leaf segment experiments, the dark acclimation was performed with leaf segments kept in the Petri dishes and these segments were wiped with towel paper prior to carry out the fluorescence measurements. The intensity and duration of the saturation light pulse were $10,000 \mu \mathrm{mol} \mathrm{m} \mathrm{m}^{-2} \mathrm{~s}^{-1}$ and $0.5 \mathrm{~s}$, respectively. The indicator of maximum quantum yield $[\mathrm{Fv} / \mathrm{Fm}=(\mathrm{Fm}-\mathrm{Fo}) / \mathrm{Fm}]$ and the effective quantum yield $\left[\right.$ ФPSII $=\left(\mathrm{Fm}^{\prime}-\mathrm{Fs}\right) / \mathrm{Fm}^{\prime}$ ] of PSII were assessed. The Fm and Fo values are the maximum and minimum fluorescence of the darkadapted leaves, respectively; $\mathrm{Fm}^{\prime}$ and $\mathrm{Fs}$ are the maximum and steady-state fluorescence in the lightadapted state, respectively; and $\mathrm{Fo}^{\prime}$ is the minimum fluorescence after the far-red illumination of previously light-exposed leaves (Genty et al. 1989; Schreiber et al. 1995).

For the PSI evaluation, the redox state of the PSI primary donor $[\mathrm{P} 700+]$ and the indicator of effective quantum yield of PSI [ФPSI $=1-\mathrm{Y}(\mathrm{N}-$ D) - Y(NA)] were measured as described previously (Klughammer and Schreiber 1998). The Y(ND) and the $\mathrm{Y}(\mathrm{NA})$ are, respectively, the non-photochemical quantum yield at the donor side of PSI $[\mathrm{Y}(\mathrm{ND})=1-\mathrm{P} 700$ reduced $]$ and the non-photochemical quantum yield at the acceptor side of PSI $\left[\mathrm{Y}(\mathrm{NA})=\left(\mathrm{Pm}-\mathrm{Pm}^{\prime}\right) / \mathrm{Pm}\right]$. Total chlorophyll and carotenoid contents were determined after extraction in ethanol and were measured spectrophotometrically at 665 and $649 \eta \mathrm{m}$. The amount of pigment was calculated using the equations proposed by Lichtenthaler and Wellburn (1983).

\subsection{Quantitative real-time PCR}

Quantitative real-time polymerase chain reaction (qPCR) experiments were carried out using cDNA synthesized from total RNA purified with Trizol (Invitrogen $^{\mathrm{TM}}$, Carlsbad, CA) as previously described in Caverzan et al. (2014). Primer pairs to amplify Osfdh3 (LOC_Os02g57040), the rice 40S ribosomal protein S27a gene (LOC_Os01 g22490) and Osfal (LOC_Os03g08020) were used as internal controls to normalize the amount of mRNA present in each sample. All qPCR assays were performed with an Applied Biosystems StepOne plus Real-Time PCR system (Applied Biosystems ${ }^{\circledR}$, Foster City, CA) using $\left(N^{\prime}, N^{\prime}\right.$-dimethyl- $N$-[4-[(E)-(3-methyl-1,3-benzothiazol-2-ylidene)methyl]-1-phenylquinolin-1-ium-2-yl]$N$-propylpropane-1,3-diamine) SYBR Green intercalating dye fluorescence detection. Transcript level determination was measured from three independent biological replicates subdivided into four analytical replications.

\subsection{APX (E.C. 1.11.1.11) activity measurement}

To prepare the enzyme extracts, fresh leaf samples were ground to a fine powder in the presence of liquid $\mathrm{N}_{2}$ using a mortar and pestle and extracted in the cold $\left(4{ }^{\circ} \mathrm{C}\right.$ ) with $100 \mathrm{mM}$ K-phosphate buffer ( $\mathrm{pH}$ 7.0) containing $1 \mathrm{mM}$ EDTA and $1 \mathrm{mM}$ AA. The homogenate was centrifuged at $15,000 \times g$ for $15 \mathrm{~min}$, and the supernatant obtained was used for ascorbate peroxidase (APX) activity assays. Ascorbate peroxidase activity was measured by following ascorbate oxidation as described by Nakano and Asada (1981) with minor modifications. The APX activity was assayed in a reaction mixture containing $0.5 \mathrm{mM}$ ascorbate dissolved in a solution containing $50 \mathrm{mM}$ K-phosphate buffer (pH 6.0) and enzyme extract. The reaction was started by adding $3 \mathrm{mM} \mathrm{H}_{2} \mathrm{O}_{2}$, and the enzyme activity was measured by following the decrease in the $290 \eta \mathrm{m}$ absorbance at $25{ }^{\circ} \mathrm{C}$ over $300 \mathrm{~s}$. To avoid interference by type III peroxidases on APX activity, two parallel determinations were performed: (A) in the absence and (B) in the presence of p-chloromercuribenzoic acid (pCMB), a specific APX inhibitor (Amako et al. 1994). The APX activity was calculated by the difference between the two parallel activities, and it was expressed as $\mu \mathrm{mol}$ ASC $\mathrm{g}^{-1} \mathrm{FW} \min ^{-1}$.

\subsection{Ascorbate and glutathione measurement}

The ascorbate content was assayed according to methods described by Kampfenkel et al. (1995). The assay is based on the reduction of $\mathrm{Fe}^{3+}$ to $\mathrm{Fe}^{2+}$ by reduced ascorbate (ASC) and the spectrophotometric detection of $\mathrm{Fe}^{2+}$ complexed with 2,2'-bipyridyl, 
resulting in a pink color. The leaf samples $(0.1 \mathrm{~g} \mathrm{FW})$ were homogenized in cold $6 \%$ trichloro acetic acid (TCA; w/v), and the homogenate was centrifuged at $12,000 \times g\left(4{ }^{\circ} \mathrm{C}\right)$ for $20 \mathrm{~min}$. The total ascorbate [ASC + dehydroascorbate (DHA)] was measured after a complete reduction of the oxidized fraction by reaction of the samples with excess dithiothreitol (DTT; $10 \mathrm{mM}$ ). Subsequently, the remaining DTT was removed by $0.5 \%(\mathrm{~m} / \mathrm{v}) \mathrm{N}$-ethylmaleimide, and DHA was calculated as the difference between the total ascorbate and ASC. Total glutathione (GSH + GSSG) was measured as described by Griffith (1980). The assay was carried out in the presence of $100 \mathrm{mM}$ sodium phosphate buffer ( $\mathrm{pH} 7.0$ ), $10 \mu \mathrm{L}$ glutathione reductase (GR, $20 \mathrm{U} \mathrm{mL}^{-1}$ ) and $6 \mathrm{mM}$ 5,5'-dithiobis-(2-nitrobenzoic acid). Absorbance was measured at $412 \eta \mathrm{m}$. The oxidized glutathione (GSSG) was measured by the same principle after incubation of $0.2 \mathrm{~mL}$ extract with $1 \mu \mathrm{L}$ VPD (2vinylpyridine) for $30 \mathrm{~min}$ at room temperature to complex GSH. The GSH content was calculated as the difference between total glutathione and GSSG. The GSH and GSSG contents were expressed as $\mu \mathrm{mol} \mathrm{g} \mathrm{FW}^{-1}$.

\section{$2.10 \mathrm{H}_{2} \mathrm{O}_{2}$ content measurement}

The $\mathrm{H}_{2} \mathrm{O}_{2}$ concentration was measured using the Amplex red hydrogen peroxide/peroxidase assay kit (Invitrogen, Carlsbad, CA, USA) according to the methods described by Zhou et al. (1997). For $\mathrm{H}_{2} \mathrm{O}_{2}$ extraction, $150 \mathrm{mg}$ of fresh leaves was ground in liquid $\mathrm{N}_{2}$, and $1 \mathrm{~mL}$ of phosphate buffer $(100 \mathrm{mM}, 7.5 \mathrm{pH})$ was added to the frozen tissue. After centrifugation, $100 \mu \mathrm{L}$ of the supernatant was incubated with $0.2 \mathrm{U} \mathrm{mL}^{-1}$ horseradish peroxidase and $100 \mu \mathrm{M}$ Amplex Red reagent (10-acetyl-3,7-dihydrophenoxazine) at room temperature for $30 \mathrm{~min}$ in the dark. The absorbance at $560 \eta \mathrm{m}$ was quantified spectrophotometrically, and the $\mathrm{H}_{2} \mathrm{O}_{2}$ content was expressed as $\mu \mathrm{mol} \mathrm{H}_{2} \mathrm{O}_{2} \mathrm{~g} \mathrm{FW}^{-1}$ as calculated from an $\mathrm{H}_{2} \mathrm{O}_{2}$ standard curve according to the manufacturer's instructions.

\subsection{Statistical analyses and experimental design}

All experiments were conducted in a factorial scheme in a completely randomized design. For the Petri plate experiments ( 2 genotypes $\times 2$ light regimes combined with 6 or 2 ASC concentrations) were employed four replicates and a dish containing 20 leaf segments represented each replicate. To the wholeplant experiments three replicates were utilized, each consisting of a 3-L pot containing two plants. The data were analyzed using one way-ANOVA, and the averages were compared by the Tukey's test at a confidence level of 0.05 , as indicated in each figure legend.

\section{Results}

\subsection{Phenotypic characterization, OsAPX gene expression and APX activity of APX7/8 mutants}

To evaluate the importance of the deficiency of both chloroplastic ascorbate peroxidases, APX7 (stroma) and APX8 (thylakoid), in AA toxicity, we used the second generation (T2) of rice plants silenced in both APX-related genes. APX7/8 plants showed no phenotypic differences throughout the developmental period compared to NT plants (Caverzan et al. 2014). The comparative habitus of 45-day-old APX7/8 (2-s)silenced and NT plants grown under normal conditions showed no difference between the plant lines in terms of morphological phenotype (Fig. S1a). The silencing reduced the transcript amounts of both OsAPX7 and OsAPX8 by $60 \%$, whereas the expression of the other APX genes (OsAPX1, OsAPX2, OsAPX3, OsAPX4 and $O S A P X 5)$ did not change under control conditions compared to NT (Fig. S1b). In addition, the APX activity in silenced plant decreased by $30 \%$ compared to NT (Fig. S1c).

\subsection{Exogenous AA caused toxicity in rice leaf segments, which was enhanced by high light}

To evaluate the potential toxicity of exogenous AA, a dose-dependent experiment with NT leaf segments was performed. This experiment was carried out with two different light regimes, low light $\left(200 \mu \mathrm{mol} \mathrm{m} \mathrm{m}^{-2} \mathrm{~s}^{-1}, \mathrm{LL}\right)$ and HL $\left(1000 \mu \mathrm{mol} \mathrm{m} \mathrm{m}^{-2}\right.$ $\mathrm{s}^{-1}$ ), during $24 \mathrm{~h}$ of incubation. Visible symptoms clearly indicated that exogenous AA concentrations at $30 \mathrm{mM}$ or higher induced toxicity in the leaf segments, which was strongly enhanced by HL (Fig. S2). These symptoms were accompanied by leaf chlorosis and cell death (necrosis). These observations were 


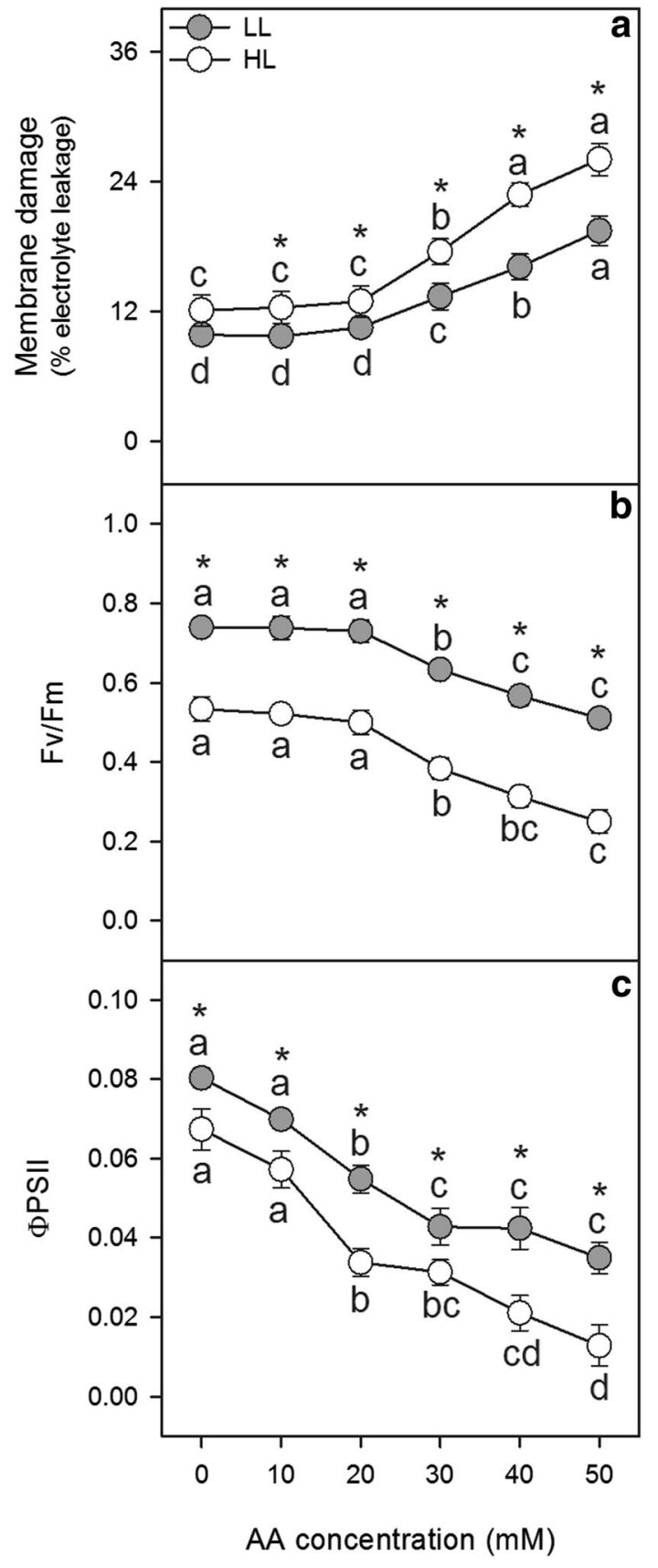

associated with an increase in electrolyte leakage, an indicator of cellular viability, which remained constant from 10 to $20 \mathrm{mM}$ AA and increased with increasing AA up to $50 \mathrm{mM}$ (a 2-fold increase overall). Inversely, Fv/Fm decreased progressively from 30 to $50 \mathrm{mM}$ AA, and ФPSII decreased gradually
4Fig. 1 a Membrane damage, b Fv/Fm and c ФPSII in nontransformed (NT) rice leaf segments treated with different ascorbic acid (AA) concentrations during $24 \mathrm{~h}$ of low light $\left(200 \mu \mathrm{mol} \mathrm{m} \mathrm{m}^{-2} \mathrm{~s}^{-1}\right)$ and high light $\left(1000 \mu \mathrm{mol} \mathrm{m} \mathrm{m}^{-2} \mathrm{~s}^{-1}\right)$. The actinic light employed for ФPSII determination was equivalent to $200 \mu \mathrm{mol} \mathrm{m} \mathrm{m}^{-2} \mathrm{~s}^{-1}$ for segments acclimated to low light regime and $1000 \mu \mathrm{mol} \mathrm{m}{ }^{-2} \mathrm{~s}^{-1}$ for the segments exposed to high light conditions. Circles represent the average of four replicates $\pm \mathrm{SD}$, asterisks indicate significant differences between light regimes within the same AA concentration, and different letters indicate significant differences between AA concentrations within the same light condition. The confidence level was 0.05

from 10 to $50 \mathrm{mM}$ (Fig. 1). All of these effects were strongly enhanced by HL.

\subsection{Exogenous AA induced proportional ASC and DHA accumulation in both the apoplast and symplast}

Both AA forms (ASC and DHA) accumulated almost linearly in response to increases in exogenous AA from 0 to $50 \mathrm{mM}$ in both plant lines (Fig. 2). The total ascorbate content varied from 6.80 to $29.80 \mu \mathrm{mol} \mathrm{g}{ }^{-1}$ $\mathrm{FW}$; ASC, from 5.48 to $24.30 \mu \mathrm{mol} \mathrm{g}{ }^{-1} \mathrm{FW}$; and DHA from 1.32 to $5.50 \mu \mathrm{mol} \mathrm{g}{ }^{-1} \mathrm{FW}$, whereas the ASC redox state was high in all treatments. In the highest AA concentration $(50 \mathrm{mM})$, the total ascorbate concentration was 29.70 and $28.50 \mu \mathrm{mol} \mathrm{g}^{-1} \mathrm{FW}$, the ASC concentration was 24.30 and $21.60 \mu \mathrm{mol} \mathrm{g}^{-1} \mathrm{FW}$, and the ASC redox state was 81 and $87 \%$ in NT and APX7/ 8, respectively (Fig. 2a, b). The AA toxicity, indicated by an increase in $\mathrm{MD}$, which was better correlated with ASC content in leaf tissue than with DHA $\left(\mathrm{r}^{2}=0.9324\right.$ and 0.5979 , respectively). To investigate if the accumulation of ASC and DHA was concentrated in apoplast or symplast, a specific experiment was carried out using NT leaf segments. Both ASC and DHA forms accumulated approximately $71.5 \%$ in symplast and $28.5 \%$ in apoplast, and the ASC redox state was similar in both compartments, with values between 80 and $84 \%$ (Fig. 2c).

\subsection{Exogenous AA induced more oxidative and physiological damage in APX7/8 compared to NT leaves under high light}

To evaluate the importance of both chloroplastic APX7/8 and HL in AA toxicity, leaf segments of both 

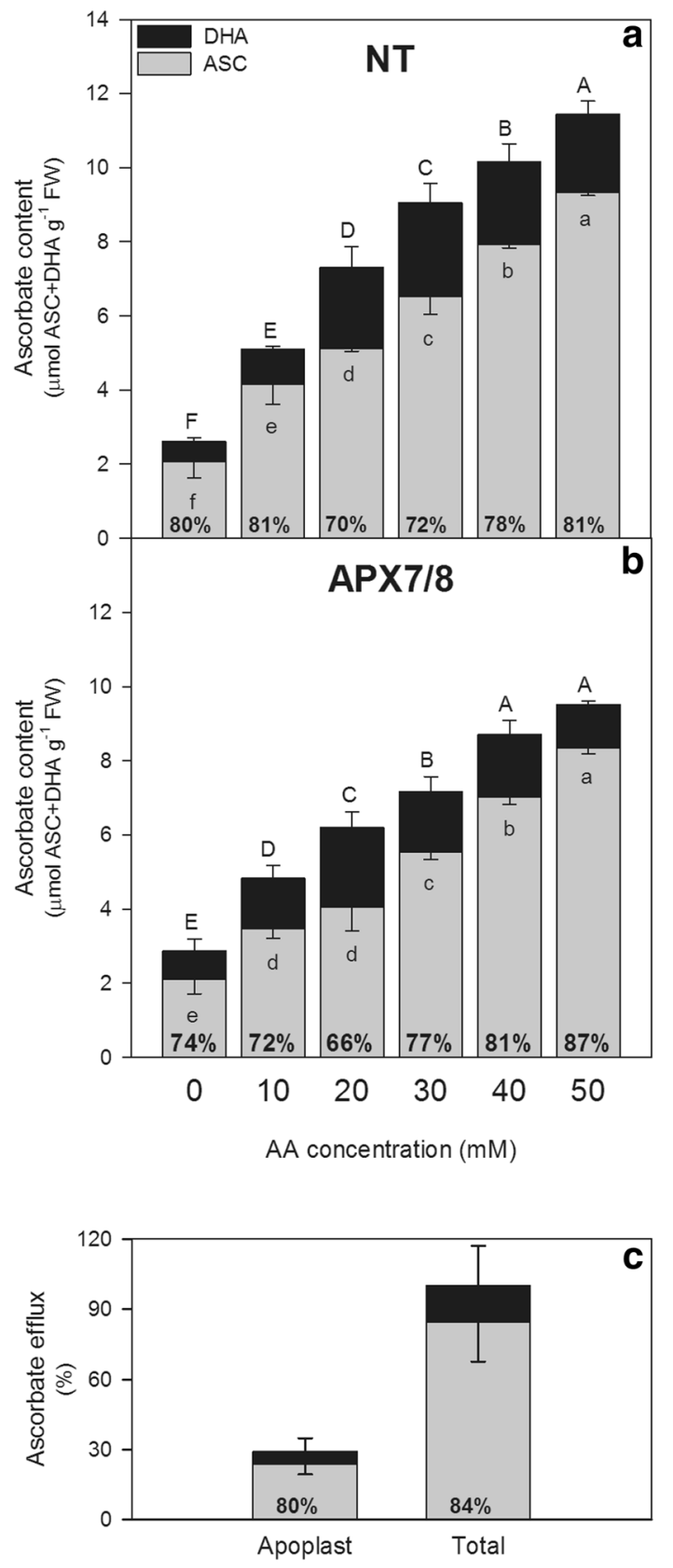

plant lines were incubated with $50 \mathrm{mM}$ AA under LL $\left(200 \mu \mathrm{mol} \mathrm{m} \mathrm{m}^{-2} \mathrm{~s}^{-1}\right)$ and HL $\left(1000 \mu \mathrm{mol} \mathrm{m} \mathrm{m}^{-2} \mathrm{~s}^{-1}\right)$. A high exogenous AA concentration induced drastic symptoms of toxicity (chlorosis and cell death) under HL, and the injuries were more severe in APX7/8 (Fig. 3). High AA provoked slight toxicity signals under LL in both plant lines. The toxicity observed on leaf segments was corroborated by the
4Fig. 2 Ascorbate levels and redox state in leaf segments of a non-transformed (NT) and b APX7/8-silenced rice plants exposed to different ascorbic acid (AA) concentrations during $24 \mathrm{~h}$ of low light $\left(200 \mu \mathrm{mol} \mathrm{m} \mathrm{m}^{-2} \mathrm{~s}^{-1}\right)$. c Total and apoplast ascorbate efflux percentage in leaf segments of NT rice plants after immersion in $50 \mathrm{mM}$ AA under low light $\left(200 \mu \mathrm{mol} \mathrm{m} \mathrm{m}^{-2}\right.$ $\mathrm{s}^{-1}$ ) for $24 \mathrm{~h}$. Bars represent the average of four replicates \pm SD. Different capital and lower case letters indicate significant differences $(p \leq 0.05)$ between bars representing total ascorbate content (ASC + DHA) and the reduced form of ascorbate (ASC), respectively. Percentage values inside the bars represent the ascorbate redox state

results displayed by oxidative stress indicators (MD, lipid peroxidation and $\mathrm{H}_{2} \mathrm{O}_{2}$ accumulation; Fig. 4). High AA under HL induced similar and severe effects on both Fv/Fm and ФPSII. In addition, the contents of the photosynthetic pigments, chlorophylls and carotenoids were also remarkably lower with $\mathrm{AA}+\mathrm{HL}$ (Fig. 5). Under HL + AA, the APX7/8 line exhibited higher levels of oxidative stress indicators and lower contents of photosynthetic pigments compared to NT plants, but Fv/Fm and ФPSII were similarly reduced in both genotypes. Under LL, the APX7/8 line did not exhibit differences in all analyzed indicators compared to NT plants (Figs. 4, 5).
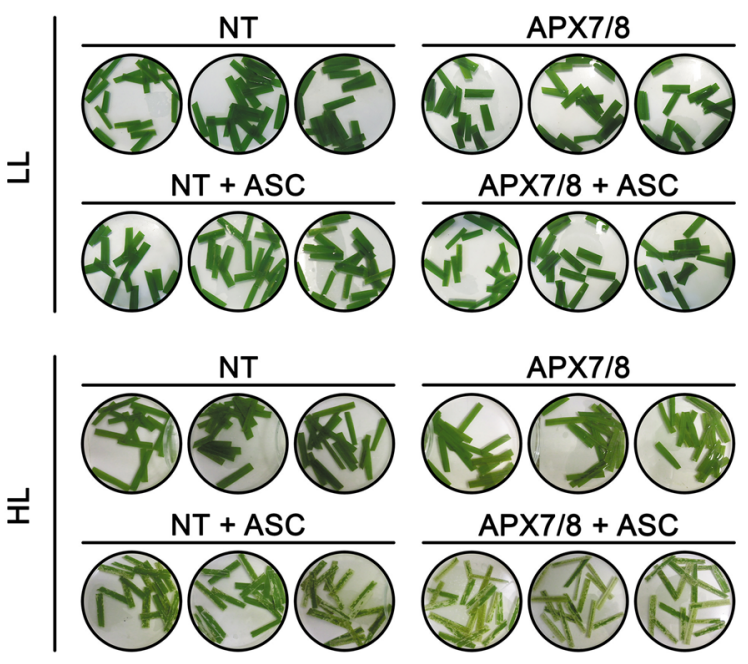

Fig. 3 Visual aspects of leaf segments of non-transformed (NT) and APX7/8-silenced rice plants treated with $50 \mathrm{mM}$ ascorbic acid (AA) during $24 \mathrm{~h}$ of low light (LL, $200 \mu \mathrm{mol} \mathrm{m} \mathrm{m}^{-2} \mathrm{~s}^{-1}$ ) and high light (HL, $1000 \mu \mathrm{mol} \mathrm{m} \mathrm{m}^{-2} \mathrm{~s}^{-1}$ ). The plates were selected as the most representative from four independent replicates 


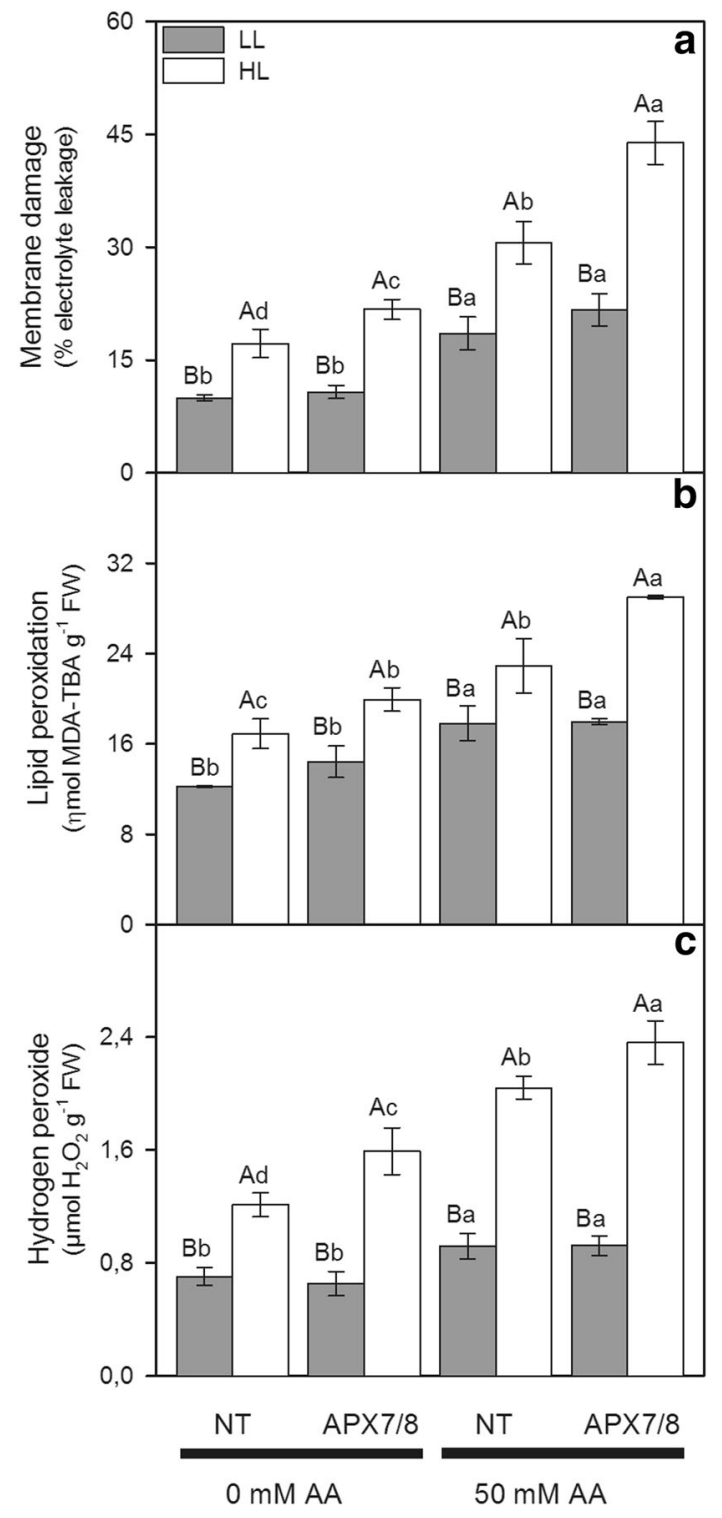

Fig. 4 a Membrane damage, b lipid peroxidation and $\mathbf{c}$ hydrogen peroxide content in leaf segments of non-transformed (NT) and APX7/8-silenced rice plants treated with $50 \mathrm{mM}$ ascorbic acid (AA) during $24 \mathrm{~h}$ of low light $\left(200 \mu \mathrm{mol} \mathrm{m} \mathrm{m}^{-2} \mathrm{~s}^{-1}\right)$ or high light $\left(1000 \mu \mathrm{mol} \mathrm{m} \mathrm{m}^{-2} \mathrm{~s}^{-1}\right)$. Bars represent the average of four replicates \pm SD. Different capital and lower case letters indicate significant differences $(p \leq 0.05)$ between light conditions and AA concentrations, respectively

\subsection{Exogenous AA induced stomatal closure} and oxidative stress at the whole-plant level

Additional experiments were performed with intact NT and APX7/8 plants exposed to $50 \mathrm{mM}$ exogenous AA under ML and HL. This experiment was

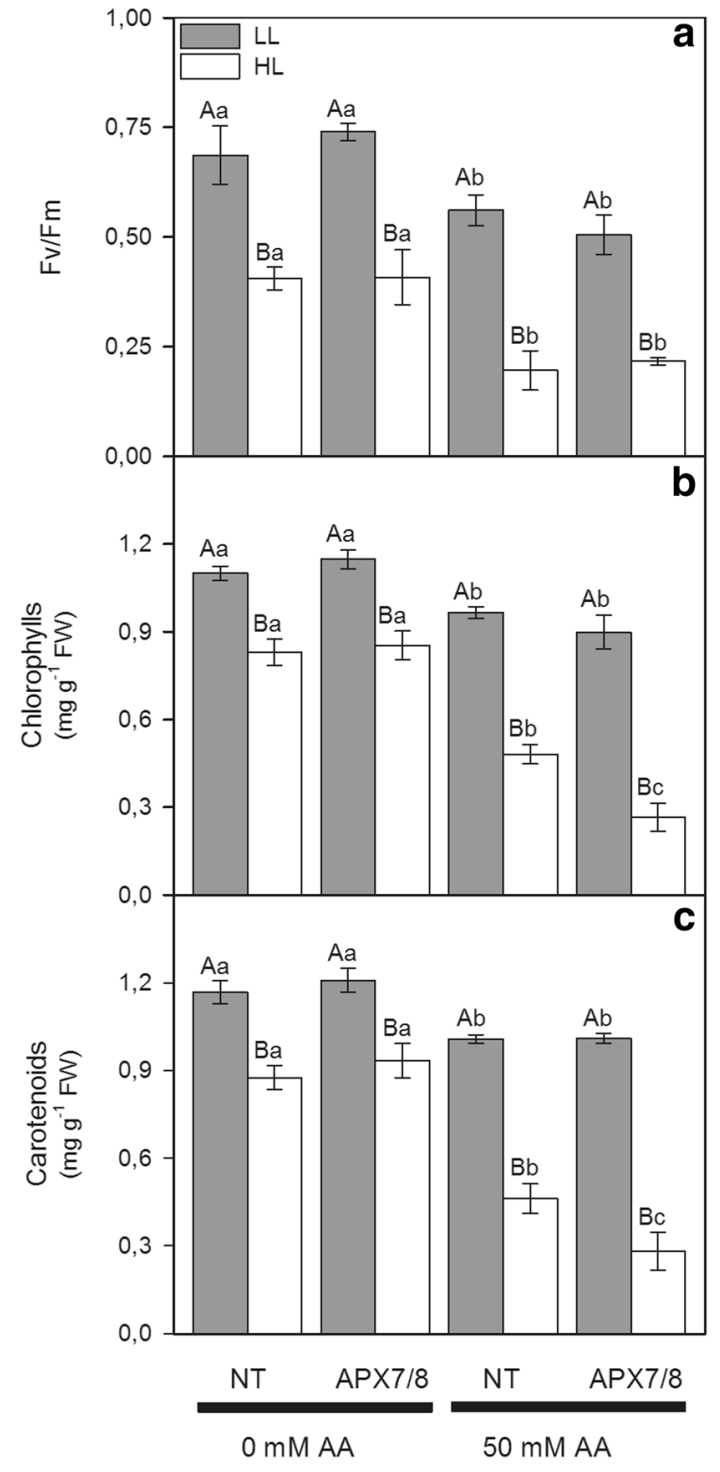

Fig. 5 a Fv/Fm, b chlorophyll and c carotenoid content in leaf segments of non-transformed (NT) and APX7/8-silenced rice plants treated with $50 \mathrm{mM}$ ascorbic acid (AA) during $24 \mathrm{~h}$ of low light $\left(200 \mu \mathrm{mol} \mathrm{m} \mathrm{m}^{-2} \mathrm{~s}^{-1}\right)$ and high light $\left(1000 \mu \mathrm{mol} \mathrm{m} \mathrm{m}^{-2} \mathrm{~s}^{-1}\right)$. Bars represent the average of four replicates \pm SD. Different capital and lower case letters indicate significant differences $(p \leq 0.05)$ between light conditions and AA concentrations, respectively

performed to confirm if AA toxicity in leaf segments occurs similarly in leaves of intact plants. The study also addressed the importance of exogenous AA on stomatal closure and its consequences on photosynthesis and oxidative stress under ML and HL. Similar to data verified for leaf segments, high concentrations of AA under HL induced higher oxidative stress, as 
Table 1 Changes in membrane damage (MD), lipid peroxidation (LP), contents of total ascorbate and glutathione, and ascorbate (ASC) and reduced glutathione (GSH) redox states in non-transformed (NT) and APX7/8-silenced rice intact leaves, control and sprayed with $50 \mathrm{mM}$ ascorbic acid (AA) or control solution under high light $\left(1000 \mu \mathrm{mol} \mathrm{m}^{-2} \mathrm{~s}^{-1}\right)$ and moderate light $\left(500 \mu \mathrm{mol} \mathrm{m} \mathrm{m}^{-2} \mathrm{~s}^{-1}\right)$

\begin{tabular}{|c|c|c|c|c|c|c|}
\hline \multirow[t]{2}{*}{ Parameters } & \multicolumn{2}{|l|}{ Control } & \multicolumn{2}{|l|}{ AA } & \multicolumn{2}{|c|}{$\mathrm{AA}+\mathrm{HL}$} \\
\hline & NT & APX7/8 & NT & APX7/8 & NT & APX $7 / 8$ \\
\hline $\mathrm{MD}^{\mathrm{a}}$ & 10.2 Ad & 11.0 Ad & $26.6 \mathrm{Bb}$ & $33.2 \mathrm{Ab}$ & $37.2 \mathrm{Ba}$ & $49.8 \mathrm{Aa}$ \\
\hline $\mathrm{LP}^{\mathrm{b}}$ & 12.5 Ad & 13.1 Ad & $20.0 \mathrm{Ab}$ & $22.9 \mathrm{Ab}$ & $42.3 \mathrm{Ba}$ & $44.7 \mathrm{Aa}$ \\
\hline $\mathrm{ASC}^{\mathrm{c}}$ & $6.7 \mathrm{Ab}$ & $6.9 \mathrm{Ab}$ & $20.9 \mathrm{Aa}$ & 19.1 Аa & $19.4 \mathrm{Aa}$ & $17.8 \mathrm{Aa}$ \\
\hline ASC redox state ${ }^{a}$ & $82 \mathrm{Aa}$ & $87 \mathrm{Aa}$ & $80 \mathrm{Aa}$ & $79 \mathrm{Aa}$ & $78 \mathrm{Aa}$ & $77 \mathrm{Aa}$ \\
\hline $\mathrm{GSH}^{\mathrm{d}}$ & 353.3 Аа & $287.4 \mathrm{Ba}$ & $150.1 \mathrm{Ab}$ & $111.2 \mathrm{Bb}$ & $84.6 \mathrm{Ac}$ & $91.0 \mathrm{Ac}$ \\
\hline GSH redox state ${ }^{a}$ & $83 \mathrm{Aa}$ & $81 \mathrm{Aa}$ & $76 \mathrm{Ab}$ & $73 \mathrm{Ab}$ & $65 \mathrm{Ac}$ & $66 \mathrm{Ac}$ \\
\hline
\end{tabular}

The data are averages of three replicates and the averages were compared by Tukey's test. Lower case letters represent significant differences between treatments within genotypes and capital letters represent significant differences between the genotypes within treatments at a confidence level of 0.05

${ }^{\mathrm{a}} \%$

${ }^{\mathrm{b}}$ nmol MDA-TBA g ${ }^{-1} \mathrm{FW}$

${ }^{\mathrm{c}} \mu \mathrm{mol}$ ASC g ${ }^{-1} \mathrm{FW}$

${ }^{\mathrm{n}} \mathrm{nmol} \mathrm{GSH} \mathrm{g}{ }^{-1} \mathrm{FW}$

indicated by higher MD and lipid peroxidation compared to control and AA under ML (Table 1). The intense oxidative stress induced by AA occurred in parallel to intense stomatal closure (Table 1).

Consistent with previous results with leaf segments, the AA-induced oxidative stress (indicated by lipid peroxidation) in HL was higher in APX7/8 compared to NT plants, but the two genotypes displayed similar responses under ML, although APX7/8 showed higher MD than NT plants (Table 1). The ASC and DHA contents strongly increased in response to $50 \mathrm{mM}$ AA treatment similarly in both genotypes, under both ML and HL, and the ASC redox state was maintained unchanged in all treatments. These results related to AA toxicity and ASC/DHA accumulation were similar to those previously observed for leaf segments in both rice genotypes. The GSH content was lower with exogenous AA treatment, and this response was intensified by HL in both genotypes. Silenced APX7/ 8 displayed lower levels of GSH in both untreated and AA-treated compared to NT plants, but in the presence of HL, they had similar glutathione levels. The GSH redox state was decreased by AA treatment, and this response was intensified under HL similarly in both genotypes (Table 1).

The application of $50 \mathrm{mM}$ AA under both light intensities induced an almost full restriction of stomatal conductance, which contributed to the intense decrease in $\mathrm{CO}_{2}$ assimilation, and this effect was greatly intensified in HL (Table 2). In addition, $30 \mathrm{mM}$ AA in the presence of ML also induced a similar increase in stomatal closure in both rice genotypes, indicating the importance of ASC + DHA for stomata regulation in rice (data not shown). These changes in gas exchange occurred in parallel to variations observed in the activity of photosystems II and I. Indeed, Fv/Fm and ФPSII were much lower with $\mathrm{AA}+\mathrm{ML}$, and this decrease was greatly intensified by HL. A similar trend was noted for the changes in the P700 redox state. The two genotypes did not exhibit significant differences in any of these parameters (Table 2).

\section{Discussion}

The results reported here demonstrate that a high concentration (above $30 \mathrm{mM}$ ) of exogenous AA under $\mathrm{HL}$ is capable of inducing strong toxic effects in rice leaves. The data suggest that the toxicity was caused, at least in part, by oxidative stress, as indicated by the increased $\mathrm{H}_{2} \mathrm{O}_{2}$ content and intense lipid peroxidation. This toxicity was induced directly by ASC because the observed toxic effects (indicated by cell integrity), were more closely correlated with ASC content than with DHA, although both compounds 
Table 2 Gas exchange and photochemical parameters of PSII and PSI in non-transformed (NT) and APX7/8-silenced rice intact leaves, control and sprayed with $50 \mathrm{mM}$ ascorbic acid

\begin{tabular}{|c|c|c|c|c|c|c|}
\hline \multirow[t]{2}{*}{ Parameters } & \multicolumn{2}{|l|}{ Control } & \multicolumn{2}{|l|}{ AA } & \multicolumn{2}{|c|}{$\mathrm{AA}+\mathrm{HL}$} \\
\hline & NT & APX7/8 & NT & APX7/8 & NT & APX7/8 \\
\hline $\mathrm{P}_{\mathrm{N}}^{\mathrm{a}}$ & $11.07 \mathrm{Aa}$ & $9.58 \mathrm{Aa}$ & $4.38 \mathrm{Ab}$ & $3.85 \mathrm{Ab}$ & $1.25 \mathrm{Ac}$ & $1.23 \mathrm{Ac}$ \\
\hline $\mathrm{g}_{\mathrm{s}}^{\mathrm{b}}$ & $0.15 \mathrm{Aa}$ & $0.12 \mathrm{Aa}$ & $0.05 \mathrm{Ab}$ & $0.07 \mathrm{Ab}$ & $0.05 \mathrm{Ab}$ & $0.06 \mathrm{Ab}$ \\
\hline $\mathrm{Fv} / \mathrm{Fm}$ & $0.69 \mathrm{Aa}$ & $0.67 \mathrm{Aa}$ & $0.59 \mathrm{Ab}$ & $0.55 \mathrm{Ab}$ & $0.29 \mathrm{Ac}$ & $0.35 \mathrm{Ac}$ \\
\hline ФPSII & $0.17 \mathrm{Aa}$ & 0.19 Аа & $0.08 \mathrm{Ab}$ & $0.08 \mathrm{Ab}$ & $0.03 \mathrm{Ac}$ & $0.04 \mathrm{Ac}$ \\
\hline $\mathrm{P} 700^{+}$ & $2.02 \mathrm{Aa}$ & $1.97 \mathrm{Aa}$ & $1.45 \mathrm{Ab}$ & $1.67 \mathrm{Ab}$ & $1.09 \mathrm{Ac}$ & $1.20 \mathrm{Ac}$ \\
\hline ФPSI & $0.32 \mathrm{Aa}$ & $0.30 \mathrm{Aa}$ & $0.14 \mathrm{Ab}$ & $0.17 \mathrm{Ab}$ & $0.09 \mathrm{Ac}$ & $0.06 \mathrm{Ac}$ \\
\hline
\end{tabular}

The actinic light employed for (DPSII and (DPSI determinations was equivalent to $1000 \mu \mathrm{mol} \mathrm{m}^{-2} \mathrm{~s}^{-1}$. Presented data are averages of three replicates, compared by Tukey's test. Lower case letters represent significant differences between treatments within genotypes and capital letters represent significant differences between genotypes within treatments at a confidence level of 0.05

${ }^{\mathrm{a}} \mu \mathrm{mol} \mathrm{m}{ }^{-2} \mathrm{~s}^{-1}$

${ }^{\mathrm{b}} \mathrm{mol} \mathrm{m} \mathrm{m}^{-2} \mathrm{~s}^{-1}$

accumulated in rice leaves. The ASC redox state remained practically unchanged, indicating low metabolism of ascorbate after absorption by leaves, as was demonstrated many years ago by Anderson et al. (1983), who demonstrated that this anion displays high uptake by isolated chloroplasts. Our data are also corroborated by other studies, which have shown that leaves are able to accumulate high amounts of exogenous ascorbate (Gest et al. 2013). This process is related to intense influx, low efflux and a low conversion rate to DHA, as was demonstrated in potato leaf discs supplied with exogenous ascorbate- ${ }^{14} \mathrm{C}$ (Imai et al. 1999).

In this study, the ASC/DHA accumulation resulted in severe physiological damage, particularly disturbances in photosynthetic activity indicated by a strong decrease in stomatal opening and $\mathrm{CO}_{2}$ assimilation associated with drastic alterations in the photochemical activity (indicated by $\Phi P S I I)$. Stomatal closure is often related to low photosynthetic electron utilization by $\mathrm{CO}_{2}$ assimilation and the generation of excess energy in chloroplasts (Foyer et al. 2012). This condition of excessive reducing power in chloroplasts is extremely favorable for the generation of ROS, such as $\mathrm{H}_{2} \mathrm{O}_{2}$, which is associated with impairment of PSII activity (Nishiyama et al. 2011) and intensification of stomatal closure (Zhou et al. 2007). Some reports have shown that increased DHA levels might induce stomatal closure, involving an increase in $\mathrm{H}_{2} \mathrm{O}_{2}$ concentration and changes in $\mathrm{Ca}^{2+}$ channels inside stomatal guard cells (Shi et al. 2012). Because the
(AA) or mock solution in the presence of high light $\left(1000 \mu \mathrm{mol} \mathrm{m} \mathrm{m}^{-2} \mathrm{~s}^{-1}\right)$ or moderate light $\left(500 \mu \mathrm{mol} \mathrm{m} \mathrm{m}^{-2} \mathrm{~s}^{-1}\right)$ 
reduction, the reduced ions can be oxidized by $\mathrm{H}_{2} \mathrm{O}_{2}$, generating hydroxyl radicals by the Fenton's reaction. The oxidized metal ions can react with $\mathrm{O}_{2}^{-\bullet}$ to produce more $\mathrm{H}_{2} \mathrm{O}_{2}$ by the Haber-Weiss reaction, inducing a dangerous oxidative cycle (Aruoma and Halliwell 1987). In parallel, the oxidized metal transition ions, such as $\mathrm{Fe}^{3+}$, also can react with $\mathrm{O}_{2}$, generating $\mathrm{O}_{2}^{-\bullet}$. The hypothesis that the ascorbate pro-oxidant action is associated with Haber-Weiss-Fenton reactions has been widely accepted by researchers working in animal systems (Miller 1969; Carr and Frei 1999; Chen et al. 2005; Vilchèze et al. 2013; Wei et al. 2017). However, this hypothesis has not been proven under in vivo conditions (Carr and Frei 1999; Proteggente et al. 2000).

Although there are several studies concerning ascorbate toxicity in other organisms, this phenomenon has been neglected in plants (Tóth et al. 2017). Upham and Jahnke (1986), using isolated spinach chloroplasts, demonstrated that superoxide could reduce $\mathrm{Fe}^{3+}$ to $\mathrm{Fe}^{2+}$ and that in the absence of this radical, ASC can replace it and perform the reduction in a similar manner. As both reactions were dependent on $\mathrm{H}_{2} \mathrm{O}_{2}$, the authors concluded that ASC could mediate Fenton reactions in chloroplasts. Ribeiro et al. (2007), utilizing purified soluble spinach chloroplast $\mathrm{H}^{+}$-ATPase FOF1, suggested that the ASC-derived ascorbyl radical was the chemical form involved with inactivation of the enzyme. Recently, Qian et al. (2014) observed that exogenous ascorbate supplied to Arabidopsis induced oxidative damage, as indicated by the accumulation of TBARS, $\mathrm{H}_{2} \mathrm{O}_{2}$ and superoxide radical. These observations were recently corroborated by Wu et al. (2017), working with rice plants exposed simultaneously to exogenous ASC and high $\mathrm{Fe}^{2+}$ concentrations, demonstrating that ascorbate can induce oxidative stress, probably via its prooxidant action.

A high ASC concentration could have initially generated $\mathrm{H}_{2} \mathrm{O}_{2}$ accumulation and further ROS accumulation by the Fenton reaction, and ROS could trigger signaling for stomatal closure mediated by $\mathrm{Ca}^{2+}$ channels in guard cells (Pei et al. 2000; Gallie 2013). Stomatal resistance is one of the major limiting factors for photosynthesis, inducing an imbalance in chloroplast metabolism, especially under HL (Wang et al. 2014; An et al. 2016). Under this condition, an excess of harvested energy occurs due to low utilization of photosynthetic electrons from photosystems by the Calvin-Benson cycle and other reactions, triggering photo-oxidative stress (Juvany et al. 2013; Dietz 2015). In this context, our results clearly show increased $\mathrm{H}_{2} \mathrm{O}_{2}$ concentration and a decrease in stomatal conductance after exogenous ascorbate exposure. We suggest that accumulation of $\mathrm{H}_{2} \mathrm{O}_{2}$ and other ROS stimulates stomatal closure, which in turn decreases $\mathrm{CO}_{2}$ assimilation, inducing photooxidative stress, which is aggravated by HL. This condition has been widely reported in plants exposed to stomatal closure and excess light (Medrano et al. 2002; Pinheiro and Chaves 2011).

Our study does not provide direct evidence that the toxicity caused by AA in rice primarily originated from the Fenton reaction. The possibility that exogenous AA caused direct toxicity in rice leaves by its acidic nature is less likely, as it was supplied in a neutralized form and because leaves treated with high AA concentrations did not exhibit toxicity symptoms when kept in the dark. Concerning the mechanisms involved with stomatal closure induced by high ASCDHA concentrations, our results are not conclusive. However, our data strongly suggest that the two

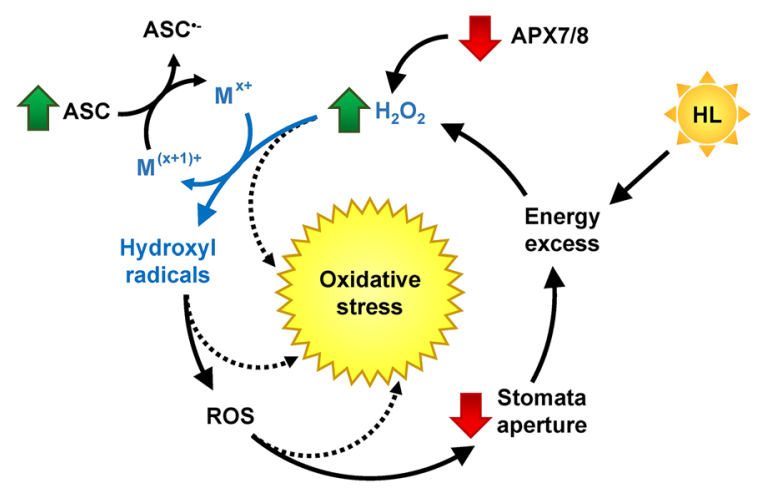

Fig. 6 Hypothetical model highlighting the probable mechanisms related to ascorbate toxicity in plants. The scheme suggests that hydroxyl radicals generated by Fenton reactions (blue), in addition to $\mathrm{H}_{2} \mathrm{O}_{2}$, are involved in stomata closure through oxidative stress signals. Fenton reactions are favored by ascorbate (ASC) application, which reduces metal species $\left(M_{n}\right)$ such as $\mathrm{Fe}^{3+}$ to $\mathrm{Fe}^{2+}$, generating ascorbyl radicals ( $\mathrm{ASC}^{\bullet-}$ ). It is suggested that stomatal closure could be induced by high exogenous AA. Because of the energy excess in photosystems, stomatal closure generates more $\mathrm{H}_{2} \mathrm{O}_{2}$, which could be used again as a substrate for the Fenton reactions in addition to $\mathrm{Fe}^{2+}$. $\mathrm{H}_{2} \mathrm{O}_{2}$ accumulation might be intensified by the low ascorbate peroxidase activity in chloroplasts (APX7/8). (Color figure online) 
processes are important for AA toxicity and that both can operate simultaneously, creating a vicious cycle. A simplified model highlighting the main processes involved in AA toxicity is presented in Fig. 6. Nevertheless, further studies involving stomata regulation employing metabolic, genetic and physiological approaches are needed to elucidate the precise factors associated with each individual mechanism.

In conclusion, we postulate that oxidative stress caused by AA toxicity under HL could have been induced by over-production of ROS due to an imbalance between excess energy in photosystems and low $\mathrm{CO}_{2}$ assimilation induced by a strong decrease in stomatal conductance. In parallel, high ASC levels could have acted as a pro-oxidant in the presence of high $\mathrm{H}_{2} \mathrm{O}_{2}$ concentrations, stimulating the Fenton reaction and consequently increasing oxidative stress in rice plants.

Acknowledgements The authors acknowledge the Conselho Nacional de Desenvolvimento Científico e Tecnológico (CNPq): Proc. 460214/2014-4 for financial support.

Author contribution JLSC performed all the experiments and contributed to manuscript writing; YLM performed gasexchange measurements and contributed to manuscript writing; FELC contributed to data interpretation and manuscript writing; AGSF contributed to biochemical analysis; MCLN performed photochemical measurements; AC obtained the silenced rice plants; MM-P designed and obtained the plant mutants; JAGS was the research mastermind and contributed to manuscript writing.

\section{Compliance with ethical standards}

Conflict of interest The authors declare that they have no conflict of interest.

\section{References}

Amako K, Chen G-X, Asada K (1994) Separate assays specific for ascorbate peroxidase and guaiacol peroxidase and for the chloroplastic and cytosolic isozymes of ascorbate peroxidase in plants. Plant Cell Physiol 35:497-504

An Y, Liu L, Chen L, Wang L (2016) ALA inhibits ABAinduced stomatal closure via reducing $\mathrm{H}_{2} \mathrm{O}_{2}$ and $\mathrm{Ca}^{2+}$ levels in guard cells. Front Plant Sci 7:1-16

Anderson JW, Foyer CH, Walker DA (1983) Light-dependent reduction of dehydroascorbate and uptake of exogenous ascorbate by spinach chloroplasts. Planta 158:442-450

Aragão RM, Silva EN, Silva PCC, Silveira JAG (2016) Saltinduced $\mathrm{NO}^{3-}$ uptake inhibition in cowpea roots is dependent on ionic composition of salt and its osmotic effect. Biol Plant 60:731-740

Aruoma OI, Halliwell B (1987) Superoxide-dependent and ascorbate-dependent formation of hydroxyl radicals from hydrogen peroxide in the presence of iron. Are lactoferrin and transferrin promoters of hydroxyl-radical generation? Biochem J 241:273-278

Blum A, Ebercon A (1981) Cell membrane stability as a measure of drought and heat tolerance in wheat. Crop Sci 21:43-47

Bulley S, Laing W (2016) The regulation of ascorbate biosynthesis. Curr Opin Plant Biol 33:15-22

Cakmak I, Horst WJ (1991) Effect of aluminium on net efflux of nitrate and potassium from root tips of soybean (Glycine $\max$ L.). J Plant Physiol 138:400-403

Carr A, Frei B (1999) Does vitamin C act as a pro-oxidant under physiological conditions? FASEB J13:1007-1024

Caverzan A, Bonifacio A, Carvalho FEL, Andrade CMB, Passaia G, Schünemann M, dos Santos Maraschin F, Martins MO, Teixeira FK, Rauber R, Margis R, Silveira JAG, Margis-Pinheiro M (2014) The knockdown of chloroplastic ascorbate peroxidases reveals its regulatory role in the photosynthesis and protection under photo-oxidative stress in rice. Plant Sci 214:74-87

Chen Z, Gallie DR (2004) The ascorbic acid redox state controls guard cell signaling and stomatal movement. Plant Cell 16:1143-1162

Chen Q, Espey MG, Krishna MC, Mitchell JB, Corpe CP, Buettner GR, Shacter E, Levine M (2005) Pharmacologic ascorbic acid concentrations selectively kill cancer cells: action as a pro-drug to deliver hydrogen peroxide to tissues. Proc Natl Acad Sci USA 102:13604-13609

Dietz KJ (2015) Efficient high light acclimation involves rapid processes at multiple mechanistic levels. J Exp Bot 66:2401-2414

Du J, Cullen JJ, Buettner GR (2012) Ascorbic acid: chemistry, biology and the treatment of cancer. Biochim Biophys Acta 1826:443-457

Eltayeb AE, Kawano N, Badawi GH, Kaminaka H, Sanekata T, Shibahara T, Inanaga S, Tanaka K (2007) Overexpression of monodehydroascorbate reductase in transgenic tobacco confers enhanced tolerance to ozone, salt and polyethylene glycol stresses. Planta 225:1255-1264

Flexas J, Ribas-Carbó M, Diaz-Espejo A, Galmés J, Medrano H (2008) Mesophyll conductance to $\mathrm{CO}_{2}$ : current knowledge and future prospects. Plant Cell Environ 31:602-621

Foyer CH (2015) Redox homeostasis: opening up ascorbate transport. Nat Plant 1:14012

Foyer CH, Neukermans J, Queval G, Noctor G, Harbinson J (2012) Photosynthetic control of electron transport and the regulation of gene expression. J Exp Bot 63:1637-1661

Gallie DR (2013) The role of L-ascorbic acid recycling in responding to environmental stress and in promoting plant growth. J Exp Bot 64:433-443

Genty B, Briantais JM, Baker NR (1989) The relationship between the quantum yield of photosynthetic electron transport and quenching of chlorophyll fluorescence. Biochim Biophys Acta 990:87-92

Gest N, Gautier H, Stevens R (2013) Ascorbate as seen through plant evolution: the rise of a successful molecule? J Exp Bot 64:33-53 
Griffith OW (1980) Determination of glutathione and glutathione disulfide using glutathione reductase and 2-vinylpyridine. Anal Biochem 106:207-212

Hu T, Ye J, Tao P, Li H, Zhang J, Zhang Y, Ye Z (2016) The tomato HD-Zip I transcription factor SIHZ24 modulates ascorbate accumulation through positive regulation of the D-mannose/L-galactose pathway. Plant J 85:16-29

Imai T, Kingston-Smith AH, Foyer CH (1999) Ascorbate metabolism in potato leaves supplied with exogenous ascorbate. Free Radic Res 31(Suppl):S171-S179

Ishikawa T, Shigeoka S (2008) Recent advances in ascorbate biosynthesis and the physiological significance of ascorbate peroxidase in photosynthesizing organisms. Biosci Biotechnol Biochem 72:1143-1154

Juvany M, Müller M, Munné-Bosch S (2013) Photo-oxidative stress in emerging and senescing leaves: a mirror image. J Exp Bot 64:3087-3098

Kampfenkel K, Van Montagu M, Inzé D (1995) Extraction and determination os ascorbate and dehydroascorbate from plant tissue. Anal Biochem 225:165-167

Klughammer C, Schreiber U (1998) Measuring P700 absorbance changes in the near infrared spectral region with a dual wavelength pulse modulation system. In: Garab G (ed) Photosynthesis: mechanisms and effects. Kluwer Academic, Dordrecht, pp 4357-4360

Kostopoulou Z, Therios I, Roumeliotis E, Kanellis AK, Molassiotis A (2015) Melatonin combined with ascorbic acid provides salt adaptation in Citrus aurantium L. seedlings. Plant Physiol Biochem 86:155-165

Lichtenthaler H, Wellburn A (1983) Determinations of total carotenoids and chlorophylls $b$ of leaf extracts in different solvents. Biochem Soc Trans 11:591-592

Medrano H, Bota J, Abadía A, Sampol B, Escalona JM, Flexas J (2002) Effects of drought on light-energy dissipation mechanisms in high-light-acclimated, field-grown grapevines. Funct Plant Biol 29:1197-1207

Miki D, Shimamoto K (2004) Simple RNAi vectors for stable and transient suppression of gene function in rice. Plant Cell Physiol 45:490-495

Miller TE (1969) Killing and lysis of gram-negative bacteria through the synergistic effect of hydrogen peroxide, ascorbic acid, and lysozyme. J Bacteriol 98:949-955

Nakano Y, Asada K (1981) Hydrogen peroxide is scavenged by ascorbate specific peroxidase in spinach chloroplasts. Plant Cell Physiol 22:867-880

Nishiyama Y, Allakhverdiev SI, Murata N (2011) Protein synthesis is the primary target of reactive oxygen species in the photoinhibition of photosystem II. Physiol Plant 142:35-46

Pallanca JE, Smirnoff N (1999) Ascorbic acid metabolism in pea seedlings. Comparison of D-glucosone, L-sorbosone, and Lgalactono-1,4-lactone as ascorbate precursors. Plant Physiol 120:453-461

Pei Z-M, Murata Y, Benning G, Thomine S, Klüsener B, Allen GJ, Grill E, Schroeder JI (2000) Calcium channels activated by hydrogen peroxide mediate abscisic acid signalling in guard cells. Nature 406:731-734

Pinheiro C, Chaves MM (2011) Photosynthesis and drought: can we make metabolic connections from available data? J Exp Bot 62:869-882

Proteggente AR, Rehman A, Halliwell B, Rice-Evans CA (2000) Potential problems of ascorbate and iron supplementation: pro-oxidant effect in vivo? Biochem Biophys Res Commun 277:535-540

Qian HF, Peng XF, Han X, Ren J, Zhan KY, Zhu M (2014) The stress factor, exogenous ascorbic acid, affects plant growth and the antioxidant system in Arabidopsis thaliana. Russ $\mathbf{J}$ Plant Physiol 61:467-475

Ribeiro AS, Souza MO, Scofano HM, Creczynski-Pasa TB, Mignaco JA (2007) Inhibition of spinach chloroplast F0F1 by an $\mathrm{Fe}^{2+} /$ ascorbate $/ \mathrm{H}_{2} \mathrm{O}_{2}$ system. Plant Physiol Biochem 45:750-756

Schreiber U, Bilger W, Neubauer C (1995) Chlorophyll fluorescence as a nonintrusive indicator for rapid assessment of in vivo photosynthesis. In: Schulze E-D, Caldwell MM (eds) Ecophysiology of photosynthesis. Springer BerlinHeidelberg, Berlin, pp 49-70

Shi YC, Fu YP, Liu WQ (2012) NADPH oxidase in plasma membrane is involved in stomatal closure induced by dehydroascorbate. Plant Physiol Biochem 51:26-30

Smirnoff N (2000) Ascorbate biosynthesis and function in photoprotection. Philos Trans $\mathrm{R}$ Soc Lond $\mathrm{B}$ 355:1455-1464

Terzi R, Kalaycioglu E, Demiralay M, Saglam A, Kadioglu A (2015) Exogenous ascorbic acid mitigates accumulation of abscisic acid, proline and polyamine under osmotic stress in maize leaves. Acta Physiol Plant 37:1-9

Tóth SZ, Lőrincz T, Szarka A (2017) Concentration does matter: the beneficial and potentially harmful effects of ascorbate in humans and plants. Antioxid Redox Signal. https://doi. org/10.1089/ars.2017.7125 (ahead of print)

Upadhyaya NM, Zhou X-R, Zhu Q-H, Eamens A, Wang M-B, Water-House PM, Dennis ES (2000) Transgenic rice. In: O'Brien L, Henry RJ (eds) Transgenic cereals. AACC, Eagan, pp 28-87

Upham BL, Jahnke LS (1986) Photooxidative reactions in chloroplast thylakoids. Evidence for a Fenton-type reaction promoted by superoxide or ascorbate. Photosynth Res 8:235-247

Vilchèze C, Hartman T, Weinrick B, Jacobs WR (2013) Mycobacterium tuberculosis is extraordinarily sensitive to killing by a vitamin $\mathrm{C}$-induced Fenton reaction. Nat Commun 4:1881

Wang Y, Noguchi K, Ono N, Inoue S, Terashima I, Kinoshita T (2014) Overexpression of plasma membrane $\mathrm{H}^{+}$-ATPase in guard cells promotes light-induced stomatal opening and enhances plant growth. Proc Natl Acad Sci USA 111:533-538

Wei X, Xu Y, Xu FF, Chaiswing L, Schnell D, Noel T, Wang C, Chen J, St. Clair DK, St. Clair WH (2017) RelB expression determines the differential effects of ascorbic acid in normal and cancer cells. Cancer Res 77:1345-1356

Wu L-B, Ueda Y, Lai S-K, Frei M (2017) Shoot tolerance mechanisms to iron toxicity in rice (Oryza sativa L.). Plant Cell Environ 40:570-584

Zechmann B, Stumpe M, Mauch F (2011) Immunocytochemical determination of the subcellular distribution of ascorbate in plants. Planta 233:1-12

Zhang X (2001) Hydrogen peroxide is involved in abscisic acidinduced stomatal closure in Vicia faba. Plant Physiol 126:1438-1448

Zhou M, Diwu Z, Panchuk-Voloshina N, Haugland RP (1997) A stable nonfluorescent derivative of resorufin for the 
fluorometric determination of trace hydrogen peroxide: applications in detecting the activity of phagocyte NADPH oxidase and other oxidases. Anal Biochem 253:162-168
Zhou Y, Lam HM, Zhang J (2007) Inhibition of photosynthesis and energy dissipation induced by water and high light stresses in rice. J Exp Bot 58:1207-1217 